\title{
IMAGENS DA INFÂNCIA, DEVIR-CRIANÇA E UMA FORMULAÇÃO À EDUCAÇÃO DO CUIDADO
}

\author{
Ricardo Burg Ceccim e Analice de Lima Palombini \\ Universidade Federal do Rio Grande do Sul, Porto Alegre, Brasil
}

RESUMO: O artigo propõe pensar o tema do cuidado a partir da noção de alteridade, afirmando uma ética do cuidado em saúde que requer exposição ao outro. Inicia trazendo elementos da história da infância para revelar suas imagens na passagem do tempo, não uma fixação conceitual. Destaca o momento de uma imagem de desvalor da criança e a exclusão da infância, projetando essa imagem para o desvalor e rejeição do contato com a alteridade. Em substituição às representações da criança, um vir-a-ser do adulto ou promessa de futuro, o artigo recorre ao conceito de Guattari e Deleuze de devir-criança para propor um cuidado que não remete às exigências do futuro, mas às experimentações em que a criança-em-nós exerce suas potências, compondo-se com os diferentes meios com que convive. Dois filmes brasileiros, Central do Brasil e Abril Despedaçado, por meio de suas imagens e personagens criança, dão corpo a essa proposta.

PALAVRAS-CHAVE: devir-criança; infância; alteridade; cuidado; educação em saúde.

\section{IMAGES OF INFANCY, BECOMING-CHILD AND A FORMULARIZATION TO THE EDUCATION OF THE CARE}

\begin{abstract}
The article proposes to think the subject of the care from the alterity notion, affirming an ethic of health care that requires exposure to the other. It starts bringing elements from the history of childhood to reveal their images in the passage of time, not a conceptual fixation. Highlights the moment of an image of depreciation of the child and the exclusion of infancy, projecting this image for the depreciation and the rejection of the contact with the alterity. In substitution to the representation of the child, a come-to-be of the adult or promise of the future, the article appeals to the concept of Guattari and Deleuze of becoming-child to propose a care that does not remit to the demands of the future, but to the experimentations in which the child-in-us exerts its powers, composing itself with the different ambients with which coexist. Two Brazilian movies, Central do Brasil and Abril Despedaçado, through its images and child characters, embody this proposal.
\end{abstract}

KEYWORDS: becoming-child; infancy; alterity; care; health education.

O menino observa a bolandeira parada, sem os bois:

_ Mãinha, eu tava pensando... O que acontecia se os boi

decidisse parar de rodar?

_ue bestagem é essa, menino?

- O que acontecia?

Nós usava os jegue.

_E se eles também decidisse parar?

_ Isso não vai acontecer. É assim desde que o mundo é mundo.

\section{Introdução}

Gostaríamos, com este texto, de compartilhar uma noção que diz respeito ao cuidado ou a uma ética do cuidado em saúde: a de que para cuidar é preciso exposição ao outro. Aceitação do outro como ele é, mas também oferta de acolhimento ao que nele pede passagem (devires, experimentação), isto é, aceitar o outro como ele é, mas também oferecer acolhimento ao "tornar-se o que se é", usando da bela e instigante imagem de Nietzsche (1888/1986) em Ecce Homo.
Este texto teve uma versão anterior, mais dedicada a pensar o tema de uma história da infância e o devir criança, interessada em ver na criança não um real ou um ideal, mas imagens. Com as imagens da criança, nesta versão, queremos fazer ver as imagens propostas ao humano e assim compreender um pouco mais sobre o jogo de captura e singularização que ocorre nos processos de subjetivação e na cultura, escrevendo sobre o tema da alteridade e pensando o tema do cuidado. Ao final do texto, dois filmes brasileiros, ambos de Walter Salles Jr., ajudam-nos com imagens e seus personagens criança, Central do Brasil (Salles, 1998) e Abril Despedaçado (Salles, 2001).

Da história da infância, tomamos, como imagem marcante, a Roda dos Enjeitados ou Roda dos Expostos, dispositivo no qual as crianças indesejadas (enjeitadas) eram expostas ao destino ou a sua própria sorte (Severo, 1996). A Roda fornecendo uma imagem ao desvalor. Da criança enjeitada à alteridade enjeitada e, com isso, 
uma imagem à exclusão tanto da alteridade como do devir-criança-em-nós: a alteridade ou o devir postos na Roda da exclusão, o desvalor de medir-se pelo outro, de contatar afetivamente com o outro, de entrar em um modo criança de contatar o outro (sentindo-o) e de compreender o mundo (explorando-o). A roda viria aí significar o movimento sem invenção, rotação sobre o que se é, sem o tornar-se. Uma roda que deve girar sobre si mesma, sem ciranda, sem circo, rotação sobre um eixo, sempre no mesmo sentido, sem produção de diferença, apenas o mesmo. Roda para não deixar ver, para não deixar dizer.

Uma imagem é uma definição de contornos ou uma territorialização, forjada pela contenção ou estase de um circuito de conexões que faz emergir as figuras da realidade (nó e conexão no tecido das subjetivações). Podemos pensar a imagem como representação e opor real e irreal, onde a noção de imaginário surge para incorporar o campo de transição entre realidade e irrealidade. Admitindo-se um modelo de verdade, o imaginário serviria para discernir verdadeiro e falso na realidade. Podemos, entretanto, pensar a imagem como configuração e, em lugar de opor o real ao irreal, captar o movimento de constituição das figuras da realidade, compreendendo a existência de uma virtualidade compondo-se com o real (no sentido de Foucault, conforme esclarece Deleuze, 1995, p. 129). Neste caso, o real é entendido como o atual (o visível das formas e o invisível das sensações, não uma fixação, mas um platô, uma metaestabilização). Sem um modelo de verdade, o falso é a potência de atualidade de uma verdade, o falso como potência de devir sobre a verdade, o imaginário como instância inventiva de imagens ou potência de atualização.

A diferença entre um imaginário representativo e um imaginário inventivo, acompanhando a formulação deleuziana (Deleuze, 1992), é que, no primeiro, as distinções real-irreal e verdadeiro-falso são substituíveis, ligadas às noções de consciência, progresso e razão, enquanto, no segundo, as distinções são reversíveis, ligadas à noção de circuitos de troca, de forma que real e virtual ou verdadeiro e falso invertem-se e reinventam-se pelo atual, compondo imagens como planos de consistência (que asseguram circuitos de troca, abertura, permeabilidade). O imaginário inventivo não busca novas sínteses ou a superação dialética, mas configurações segundo a necessidade de afirmar, não o que seria mais verdadeiro, mas as potências criativas. Em vez da busca da essência, da origem, da evolução ou da consciência racional, ao imaginário inventivo interessam as simulações (autorização, permissão, experimentação..., sem certezas, razão, explicação). Buscamos as imagens para revelar o que está dado ou as motivações para determinado estado de realidade, mas também para tornar visível aquilo por dar-se ou a existência de um campo de possíveis.

Deleuze (1992), estudando sobre cinema, passou a formular uma noção de imaginário como cristais de tempo, dizendo que aquilo que se vê no cristal são imagens de tempo (potências do falso); o imaginário, então, seria uma imagem-cristal. Deleuze recusa atribuir-lhe irrealidade; vê o imaginário como um conjunto de trocas entre uma imagem real e uma virtual, como uma indiscernibilidade entre o real e o irreal, o que coincide com a sua noção do falso e verdadeiro, ambos jogos de composição e de desafio. Quando em oposição, cristalizam representações; quando constituem tensões, ativam imaginações. A ultrapassagem do real é com o imaginário reconfigurando o real. O imaginário é a potência do falso, substituindo o verdadeiro pela potência do devir. Uma imagem-cristal não leva a um imaginário das representações (congelamento do tempo), mas a um imaginário dos desafios e das desestabilizações (invenção de tempo, campos de possível).

Paul Klee falava que sua arte não podia refletir a superfície (isto que uma chapa fotográfica pode fazer) porque refletia até o coração; por isso, seus retratos (rostos humanos) eram mais verdadeiros que os originais (Luzán, 1998). Klee fala de uma interioridade que se distingue claramente da superfície, sem opor aparência e essência. Não é a essência que precisa ser buscada, mas o circuito de conexões invisíveis (íntimas, por acoplamento afetivo, páticas) que compõem o real e só podem ser captadas, não fotografadas. Klee é um artista, e é da arte a singularidade de dar visibilidade ao invisível, escutar/ver o inventivo sob o representativo e torná-lo visível/audível. É própria à arte essa condição sensível e de contato com a alteridade.

Essa sensibilidade artista é como a sensibilidade infantil, pura abertura. É das crianças a invenção e a criatividade ou a facilidade de enveredar pelos estranhos e insólitos universos do jogo, do desenho e dos brinquedos. O imaginário-criança é o das afecções sensíveis, dos acoplamentos cognitivos, da invenção de linguagens para descobertas vividas. Um imaginário-criança não busca o verdadeiro, experimenta. Não analisa logicamente, deixa-se afetar. Não se prende a identidades e limites, embarca na expansão.

O modelo de caracterização do humano que veio sendo construído no plano da visibilidade (no interior da moral e da lei) desde a Antiguidade até a Modernidade é o modelo de homem como sexo masculino, raça branca, adulto, de orientação heterossexual, detentor das faculdades de raciocínio lógico e consciência, possuidor de grande força física, que dá nome à família, possuindo bens e patrimônio que honram esse nome. Temos aí uma representação proposta como ideal, um imaginário representativo (fixação, identidade, forma). A qualquer 
dessas tendências, quando dirigidas à configuração das formas da subjetividade, chamamos forma homem (Deleuze \& Guattari, 1997). São essas tendências que justificam, na modernidade, a criação da categoria "diferente" para designar, entre os humanos, a criança e também a mulher, os loucos, os deficientes mentais, os negros, a orientação homoerótica... Do ponto de vista da forma homem, tais variedades são linhas de fuga em cujo fluxo se traçam devires (potências do falso sobre a verdade da forma). Acompanhar seus fluxos, recuperando essas potências do humano, significa a ruptura com a imposição da exclusão das mesmas na composição do ver, dizer e julgar. Sigamos, então, pelas linhas que nos abrem as imagens da criança.

\section{A exclusão da infância}

Reaver as práticas históricas de como as sociedades tratavam as crianças ou como lidavam com a infância nos defronta com a construção histórica dos conceitos morais de civilização, razão, consciência e perfeição humana. Se hoje entendemos por condição especial das crianças o fato de estarem em fase de intenso crescimento físico e desenvolvimento psíquico, o que veio lhes dar, acima mesmo da moral, garantias legais de preferência no direito à saúde e à educação, não podemos deixar de lembrar que, até o início do século XVIII, o crescimento e o desenvolvimento (hoje ação programática da puericultura em psicologia, enfermagem, medicina...) significavam debelar e rejeitar o estado infantil em que os homens se encontravam nas idades precoces. $\mathrm{O}$ pensamento social vigente propunha que os homens se faziam humanos pela expulsão de tudo que neles houvesse da criança. O modelo de homem era o adulto racional e consciente da realidade.

Era pela luta contra o que de infância houvesse em nós que poderíamos nos alçar à humanidade e à cidadania. A infância não se confundia com ingenuidade; identificava-se com animalidade e com incapacidade: ausência de razão, de domínio linguístico e de consciência moral. Entendia-se que uma criança aprendia com o corpo e não com o intelecto, sua vontade era instintiva e não crítica; logo, faltava-lhe caráter, inteligência e competência humana.

O historiador francês Philippe Ariès (1979) estudou a transformação dos sentimentos de infância e de família, pesquisando as criações artísticas na pintura, na decoração de igrejas, em túmulos e em fontes documentais, como os testamentos e os diários de família. Legou-nos, desse modo, uma História social da criança e da família que nos permite detectar o surgimento da família nuclear, da escola e do sentimento de infância contrapostos à hipótese de que família e escola sempre existiram e sempre tiveram a mesma designação social ou de que uma natureza infantil sempre caracterizou a criança como alvo de carinho, proteção e amor parental.

Outra extensa pesquisa dos costumes e da história social foi empreendida pela filósofa Elisabeth Badinter (1985), que retomou a história e os comportamentos sociais para examinar a condição da maternidade em $O$ mito do amor materno, revelando o sentimento de amor materno como um sentimento humano entre outros, não indefectível. Badinter deteve-se nos comportamentos de pais, mães e filhos, oferecendo-nos densos elementos para compreender a condição das crianças. No Brasil, um estudo de fôlego semelhante é apresentado pelo médico sanitarista e psicanalista Jurandir Freire Costa (1989) em Ordem médica e norma familiar, onde vasculhou, com cuidadosa pesquisa, a história dos comportamentos relativos à infância e à família na época colonial.

\section{A roda dos enjeitados, as Casas da Roda}

A ausência de um sentimento de infância, tal como o conhecemos hoje, atravessou a história da humanidade, registrando épocas de grande abandono e mortandade das crianças. Antes da era cristã, as crianças indesejadas eram expostas à morte, sendo empilhadas em monturos públicos de deposição dos enjeitados, colocadas em barcos e lançadas ao mar, largadas no campo ou na rua para que fossem recolhidas por algum interessado ou devoradas por insetos rasteiros, cães e outros animais. Podiam ser queimadas em fogueiras de dejetos ou sacrificadas em rituais místicos ou religiosos; ou, ainda, eram mutiladas para justificar o pedido de esmolas ou apelo de ajuda socioeconômica por adultos pobres, comerciantes decadentes e escravos fugidos. $\mathrm{Na}$ Antiguidade, o infanticídio era prática comum e até incentivada, inclusive como proposta política de controle populacional. $\mathrm{O}$ infanticídio era ainda tão frequente até o século XIII que os hospitais foram orientados pela igreja a receber e recolher crianças abandonadas para que não se acumulassem tantas mortes miseráveis (Ariès, 1979; Badinter, 1985; Freire Costa, 1989).

Robert Darnton (1986) mostra que muitos dos contos infantis hoje acusados de perversão contra crianças, como os contos de Chapeuzinho Vermelho e de João e Maria, narravam, em verdade, experiências da vida cotidiana das famílias camponesas ${ }^{1}$. Essas práticas perduraram em maior ou menor proporção durante o século XVIII.

Até o século XII, não constavam crianças nas criações artísticas e nem mesmo a pintura retratava a imagem corporal de crianças. Os artistas pintavam as crianças como adultos em tamanho reduzido, ou seja, não havia uma imagem social para a criança; ela não era nem mesmo o adulto em potencial ou em crescimento: 
era já o adulto, ainda que em miniatura (Ariès, 1979). No século XIII, o hábito de entregar um filho a Deus, passando sua educação à Igreja para que se tornasse frei ou freira, disseminou-se entre as famílias pobres como reivindicação do direito à honra e ao respeito social, dando lugar ao frequente abandono de crianças diante das portas de igrejas, mosteiros e conventos. No século XV, durante a Renascença, passamos a ver a criança retratada na pintura, como anjinhos róseos ou azuis-claro. Da mesma forma, a escultura tornavase plena de personagens infantis angelicais: risonhos, bochechudos e roliços. Os anjos - os putti da pintura e escultura medievais - podiam ser nus e sexuados e iam de Eros ao Menino Jesus. Assim, atribuía-se uma imagem à infância: representação do ingênuo, do inocente, do bom e puro, em íntima conexão com o paraíso e o reino dos céus. Numa época em que a mortalidade infantil era extremamente elevada, a criança morta era um anjo que ia para o céu, pois uma alma pura só poderia encontrar o reino do paraíso.

Como reserva de pureza e inocência, a criança revelava o tempo da ausência de moral e pudor a serem conquistados e nunca mais perdidos: ela podia andar nua; o adulto, não mais. Ser criança era ser ninguém, mas um ninguém que virá a ser. A criança passava a ser o signo da alma do adulto, imagem da esperança, promessa de vir-a-ser. Somente almas puras (obedientes, tementes e amantes de Deus, do patrão e do poder) podiam alcançar o paraíso. Alcançar o paraíso era a promessa que só seria atingível após a morte. É com vistas ao adulto por vir que, no século XVI, difundiramse os colégios, claramente orientados pela segregação da criança, seu adestramento moral, disciplinamento físico e rigidez de pensamento. Os colégios religiosos e filantrópicos acolhiam crianças pobres e sem família, funcionando como instituições reformadoras e de prevenção da delinquência, como se fossem abrigos de polícia social (Casas de Recolhimento). Durante o século XVIII, na Modernidade, as crianças eram submetidas às mais severas restrições e proibições: utilizadas para trabalhos de grande risco como a limpeza das chaminés industriais (já que podiam penetrá-las); abusadas fisicamente por circuncisão, infibulação, castração ou clitoridectomia; fechadas em emplastros de folhas, couro ou borracha; acorrentadas, surradas, amedrontadas e castigadas (Oliveira, 1993). Viver, para a criança, reduzia-se a permanecer viva.

$\mathrm{O}$ abandono de crianças ao longo de toda a história foi tão frequente que a assistência às crianças expostas materializou-se em instituições de finalidade específica - as Casas dos Expostos ou Casas dos Enjeitados, também conhecidas como Casas da Roda, pela evidência do dispositivo que lhes dava existência, a Roda dos Expostos ou Roda dos Enjeitados. Este era um dispositivo giratório posto por uma fenestra na Casa da Roda, uma parede na qual havia um balcão: girado para fora, o balcão permitia que ali fosse depositada a criança enjeitada; girado, então, para dentro, possibilitava que a criança fosse recolhida por funcionários da Casa. Ao girar a Roda, soava uma sineta que avisava aos funcionários a deposição de mais um bebê. A identidade daquele que abandonava a criança permaneceria desconhecida para sempre, e o futuro da criança para sempre desconhecido daquele que a abandonara. Inventada no século XIII, as Rodas dos Enjeitados chegaram ao Brasil em 1726, sendo instaladas nas Santas Casas de Misericórdia das principais cidades brasileiras. A primeira foi instalada em Salvador (1726), seguida pela do Rio de Janeiro (1738), Recife (1789), São Paulo (1825), São Luiz (1829) e Porto Alegre (1837). Esta última, que funcionou durante 103 anos, foi desativada apenas em 1940 (Severo, 1996).

\section{Sua majestade, o bebê}

Tomando-se as imagens históricas da criança, pode-se perceber as configurações históricas com que se impunham as imagens do direito à vida e ao saber: um limite representativo do humano. A imagem da criança mais comum na história é a do filho, uma imagem sem qualquer especificidade ou peculiaridade ligada à infância. Do ponto de vista afetivo, sua posição é suplementar (como um adicional, um acréscimo), e não complementar (como exigência afetiva para suprir e completar o núcleo familiar); é instrumental (pode ser chamada a exercer certas funções econômicas, sociais ou de poder na família ou sua linhagem), embora não tida com o caráter utilitário como aquele com que se têm os escravos ou servos.

A mulher e os filhos compõem a célula primária dos direitos do pai, dando configuração e consistência ao seu poder. É o pai o alvo de direitos, atenção, cuidados e proteção especial - o que podemos reconhecer como vigente até bem pouco tempo em nossa organização social. Não havia positividade em ser criança; sê-lo era ser incompleto e incompetente, era preciso crescer para se tornar competente naquilo que se é: um adulto. O universo das subjetivações, desde a Antiguidade até a Modernidade, remetia ao culto à propriedade, ao passado e às leis divinas. Ao pai cabia a imagem da propriedade, do passado e da lei, donde advém, na linguagem, o chefe da família, a casa paterna, o pátrio poder, o homem da casa, termos a partir dos quais se constituem, como seu desdobramento, as imagens da mulher, do filho e dos adultos não pais, entre a parentela.

É preciso entender que, durante todas as épocas históricas em que se conviveu com a escravidão e servidão de concidadãos, a liberdade era o equivalente de 
propriedade. Nos regimes em que a polarização social se deu entre proprietários e escravos/servos, as lutas sociais esgotavam-se entre apropriar-se (ter posse) e ser apropriado (nada possuir). Os homens livres representavam a menor proporção dos cidadãos da Antiguidade e da Idade Média. As chances de liberdade (escapar da polarização da propriedade) eram mínimas e extremamente difíceis de alcançar - a igreja, a sapiência filosófica, o artesanato, o pequeno comércio, o trabalho médico e o trabalho jurídico foram as alternativas históricas mais frequentes e terminaram por constituir novas imagens representativas para a liberdade.

A vivência passada, o entendimento do passado e a sua reverência tornavam respeitável o adulto e venerável o idoso. Ao homem responsável, cabia controlar a mulher, os filhos e os escravos (ignorantes ou inocentes, menos racionais e menos lógicos), e estes deviam respeito ao pai de família (patrão e protetor). Sobre as filhas, os poderes do pai eram ilimitados, uma vez que se sobrepunham, nelas, a mulher, a criança e a filha. As leis do pai ou leis do patriarca ou leis divinas davam forma ao prestígio e à honra do nome do pai, à manutenção das tradições e continuidade sagrada da moral. As leis renovavam a mentalidade patriarcal e justificavam os castigos físicos e a obediência incontinenti ao pai. As crianças eram punidas com farta violência física (é fácil recuperarmos da história as palmatórias, as varas de marmelo, os galhos de goiabeira, entre vários métodos, mas havia outros: objetos de sevícia e duras humilhações psicológicas).

Os pais eram patrões e gozavam da autoridade de patriarcas e protetores, constituindo-se em reserva e fonte da subsistência pelas vias de conquistar alguma propriedade, representar e dignificar o passado e consagrar a moralidade. O pai era a garantia de vitalidade da família. A geração e conservação de bens e posses promoviam a família em conjunto e cada um de seus membros. O poder, o prestígio e a honorabilidade acumulados pelo pai se estendiam para toda a família, da mesma forma que as suas derrotas. A religiosidade na cultura medieval, ao investir a criança com a figura do anjo, ofereceu aos séculos seguintes uma imagem da importância da obediência, do respeito ao pai e do respeito às regras, como se pregava para o adulto em relação à igreja e a Deus (era o respeito e a obediência que levariam à perfeição da alma). A vida estava representada pela obediência, e a criança, que já representava essa obediência, passava a encarnar a pureza e a inocência como um signo; não implicava ser amada e cuidada.

Assim, até o século XVIII, a alta mortalidade infantil não chegava a mobilizar a preocupação da sociedade. É apenas na passagem do século XVIII ao século XIX - quando a necessidade de preservação da Força de Trabalho impõe-se como exigência do processo de industrialização urbana - que a mortalidade infantil tornou-se alvo da ação de moralistas, administradores e médicos, dando origem ao discurso da maternidade, com o qual se inaugurava um modo novo de subjetivação (Badinter, 1985). A preocupação dos higienistas não era, então, com as crianças, mas com a contenção epidemiológica dos adoecimentos e da mortalidade. As doenças comuns da infância só eram conhecidas por seu potencial epidêmico, e não pelo interesse de uma atenção ou proteção à saúde das crianças ${ }^{2}$. Uma vez que, até o século XIX, mais de $50 \%$ da mortalidade geral ocorria em menores de seis anos, estes se tornaram alvo prioritário das campanhas higiênicas. No que se refere à saúde individual, alguém teria que ser responsabilizado pela vigilância sanitária.

Dessa forma, surgiam os deveres da mãe para com a maternidade, que, em seu conteúdo discursivo, prescrito pelos movimentos moralistas de higiene social, visava a conter a disseminação das doenças e mortes na sociedade. Os deveres da mãe iniciavam com a gestação, prolongavam-se pela amamentação do filho até o surgimento da primeira dentição e na oferta de cuidados de higiene corporal e vestimentas ao bebê. Porém, como a mortalidade infantil era indubitavelmente maior entre os menores de um ano e, nestes, recaía massivamente sobre os menores de 30 dias, os higienistas elegeram a amamentação e o cuidado materno ao recém-nascido como o alvo de sua maior teorização, pesquisa e educação social. A mãe deveria então dedicar a vida ao seu filho pequeno, pois dessa dedicação dependeria a sobrevivência, saúde, beleza física e vitalidade da criança.

Com efeito, entre as práticas relacionadas com alta prevalência de mortes infantis estavam a confiança dos bebês às amas-de-leite, a amamentação por amas mercenárias, a entrega de bebês aos asilos e orfanatos e o abandono de crianças. A prática de depositá-las nas Rodas dos Enjeitados tornou-se alvo dos higienistas porque, criadas para proteger da morte as crianças indesejadas (os enjeitados), registravam altas taxas de mortalidade infantil. Assim, a prevenção das mortes precoces articulava-se à contenção dos nascimentos, e todo um discurso médico passou a recair sobre a higiene da maternidade: casamento, fidelidade conjugal, ausência de prazer sexual e longo espaçamento da prática sexual após um nascimento.

As crianças que eram entregues às Rodas eram crianças filhas de uniões adúlteras; uniões proibidas pelos pais; filhos de escravos que tentavam salvar suas crianças da escravidão; filhos de escravas com o patrão ou com os filhos do patrão; filhos que resultavam de prostituição ou de estupros; bebês que nasciam com deformidades ou doenças; bebês de partos complicados; bebês de famílias já muito numerosas; filhos de 
mulheres que preferiam comercializar seu leite materno e obter renda; filhos sequestrados das escravas por seus patrões para alugarem seu leite materno; filhos de jovens prometidas pelos pais etc.. As Rodas terminavam por acusar, nas estatísticas higiênicas, um número elevado de nascimentos ilegítimos, uma altíssima proporção de partos mal realizados e de mortes no primeiro mês e no primeiro ano de vida, a falta de higiene do meio social, os abusos morais e sexuais, entre outras características das más condições de vida da população. Enquanto os higienistas definiam padrões de moralidade e sanidade às populações, as Rodas, inesperadamente, competiam pela inutilidade dos valores morais pregados, evidenciando, sem disfarces, a realidade da exclusão e, em especial, a supressão do contato com o outro pela recusa ao seu acolhimento.

Buscando minorar essa realidade, a disciplina da higiene materno-infantil impôs-se como prioridade no estudo da saúde pública e da educação e cuidado dos filhos, alçando a criança a um novo lugar social, identificada, cada vez mais, como alvo de cuidados, desvelo e amor. Uma nova ordem familiar começava a desenhar-se, desde a passagem do século XVIII ao XIX e na consolidação dos desígnios da subjetivação no novo século, em torno à figura de "sua majestade, o bebê". Tal expressão, da qual Freud (1914/1974) irá servir-se em seu trabalho sobre o narcisismo, tem nascimento no bojo dessas práticas higienistas voltadas ao cuidado do recém-nascido como foco privilegiado por meio do qual se alcançava a saúde da população. Podemos considerar que, no passado, assim como na atualidade, a mesma expressão, alçando o bebê à majestade, investindo-o de valor sacro e fálico, encontra seu reverso no uso da criança como objeto de gozo, de comércio e de morte.

\section{Pai provedor, mãe educadora}

Para atenuar a mortalidade infantil e melhorar a saúde nas cidades, com a ascensão dos conglomerados urbanos, era preciso modificar o sentimento de poder dos homens. Modificar o sentimento de poder dos homens significava conter-lhes os abusos diante de escravos, filhos e esposas; as mulheres e as crianças em geral. Uma súmula da higiene doméstica poderia resumir-se em: pai provedor, mãe educadora, criança em crescimento e desenvolvimento físico, moral e intelectual no seio de um lar com vistas ao bom serviço à sociedade.

Novas relações econômicas levavam ao surgimento de uma ciência do Estado. O movimento de unificação da Alemanha, dando nascimento à imagem de Estado moderno, depunha em favor da nova lógica social em curso no que se refere à família e à criança.
Estava sendo gestado o Estado-nação, onde todos os cidadãos são filhos da nação e devem respeito ao paiEstado, seu protetor. Para fazer nascer o sentimento de nação, era preciso redefinir os papéis dos pais e das crianças, cabendo a toda família a devoção ao Estado que seria uma devoção à humanidade. Os pais, portanto, não poderiam mais ser proprietários, mas tutores dos filhos da nação, os cidadãos do futuro. Precisava-se de mais pais e menos patrões, para que todos servissem ao capitalismo monopolizante.

A modernidade impôs um novo modo de vida, nascido no final do século XVIII, mas que se desenvolveu e criou raízes na subjetividade ao longo do século XIX. Um modelo de vida voltado para a interioridade e intimidade do lar e da família, de onde sobrevinham laços amorosos que esgotavam a vigência exclusiva dos laços consanguíneos aprendidos da família feudal. A mãe passou a ser o centro da célula familiar e a matriz dos afetos dos filhos. A higiene e a medicina social nascentes nesse mesmo período não somente contribuíram para a emergência desse sentimento como lançaram as bases de uma vigilância extremada sobre os hábitos, condutas e atitudes da população, disciplinando intensamente a vida e os conceitos de saúde e doença. Foucault (1992), em O nascimento da medicina social, descreve essa normalização médica da vida social segundo as vertentes da saúde pública: a Polícia Médica (alemã), a Medicina Urbana (francesa) e o Sanitarismo (inglês).

A educação das crianças em colégios entrava neste perfil de vigilância e disciplinamento do corpo e da mente, apresentando-se como única saída para formar cidadãos com retidão moral, capazes de amar e servir à Humanidade e detentores do conhecimento competente para explicar o mundo e as relações entre os homens. Se amar aos filhos tornava-se fundamental para a sua sobrevivência, educá-los corretamente era a única garantia de que se tornariam os adultos desejados pela sociedade. O discurso da medicina social era o de que as famílias não sabiam amar, esqueciam-se de regras morais, adulavam as crianças e expunham-nas às experimentações da rua. Era preciso saber onde se esgotava o papel materno e onde começava o papel do colégio. À mãe, portanto, caberia o período do aleitamento, das fraldas, de aprender a falar, andar e controlar os esfíncteres, aprender a vestir-se e calçar-se sozinha e a assumir sua própria higiene. A seguir, a criança de boa família ou que visasse à melhor integração social deveria ser enviada ao colégio, os mais eficazes sendo os colégios internos. Todas as saídas do internato colegial, os contatos com a rua e o próprio retorno ao convívio familiar eram acusados por pedagogos e médicos como perigosos porque as crianças teriam acesso a conversas indiscretas, à leitura de romances, aos entretenimentos 
secretos, à masturbação, às perversões morais que grassavam entre os iletrados, os vadios e devassos.

No colégio, a criança abandonaria seus afetos infantis para aprender o que é o belo, o bom e o honesto. Um novo homem e um novo mundo teriam seu começo nos bancos escolares, submetidos às mais criteriosas regras pedagógicas e ao mais criterioso conhecimento científico. Mas de lócus privilegiado das normas de ser e das ordens médicas, o internato passou a repercutir, inesperadamente, em incitação à masturbação e à homossexualidade. Impossíveis de conter, as singularizações da subjetividade e da cultura sobressaíam (linhas de fuga, passagem pelas figuras da proibição/exclusão), o devir impunha cirandas à roda, invenções de tempo (o contato com os devires), deformando a tentativa de congelar o tempo (não sem novos sofrimentos). Aos poucos, o discurso da alegria na escola ganha vigência nas representações pedagógicas e populares e as escolas recebem a influência de modelos cada vez mais diversos. Da mesma forma, os estudos sobre a educação infantil passam a refletir novas ordens sobre as aprendizagens cognitivas e as significações do brinquedo e do brincar para a criança. A puericultura se atualiza com os movimentos de mulheres no mundo todo. Sob a pressão destas, o pai se defronta com a maternagem. A mortalidade infantil se reduz drasticamente e a natalidade também. O que as relações sociais e econômicas da modernidade instauraram na subjetivação da criança e da família é que a criança era o vir-a-ser. Ela seria tudo o que não conseguimos ser. A criança passou a encarnar uma promessa, um pacote de subjetividade voltado para o futuro, sua nova imagem. Pais, educadores e sanitaristas apontavam os caminhos que as crianças deveriam seguir para se tornarem um adulto conforme a esse futuro projetado.

\section{$O$ infantil como presença atemporal no adulto}

É somente no século XX, portanto, que a infância passa a ter reconhecimento como etapa especial da vida, determinante do desenvolvimento físico e psíquico do homem. Trata-se do resultado de um processo que, conforme vimos, iniciado nos séculos anteriores, irá tornar a família permeável à ordem disciplinar na qual se engendram, ao longo do século XIX, os saberes $p s i$. A psicanálise, a que Foucault (2006) se refere como o mais "família" do todos os discursos psicológicos, tem papel preponderante nesse processo e na visada de que a criança passa a ser alvo - objeto de intensa afeição, signo de desvelo e amor materno ou parental. Contudo, se a invenção freudiana de conceitos como o de inconsciente, pulsão, recalque e fantasia, traz, em seu bojo, a ideia do infantil como constituinte do psiquismo adulto, não é a infância, tal como vivida na realidade, o que importa à experiência analítica em Freud, mas a construção, a posteriori, dos desejos, fantasias e recordações que recobrem os primeiros anos de vida, cujas marcas, inacessíveis à consciência, são, porém, determinantes do psiquismo (Zavaroni, Viana, \& Celes, 2007).

Assim, em $A$ interpretação dos sonhos (Freud, 1900/1972), o retorno do infantil recalcado encontra no sonho a sua via privilegiada - não na literalidade das experiências que originaram suas marcas, mas por meio de representações que as deslocam e condensam, levando ao trabalho de reconstrução/construção do infantil que é, por definição, o trabalho próprio à análise na tarefa de desvelamento do inconsciente. Um pouco mais tarde, em Três ensaios para uma teoria da sexualidade (Freud, 1905/1972), é a sexualidade perverso-polimórfica, própria ao exercício livre das pulsões, o que caracteriza o infantil e persiste, como tal (atemporal), apresentando-se subjacente à sexualidade do adulto. E mesmo quando Freud (1909/1974) ocupa-se em acompanhar o que seria o trabalho de análise da fobia de um menino de cinco anos, por meio dos relatos e da intervenção do pai da criança, o que se dá a ver são as fantasias e recordações que se constroem em torno a uma experiência originária que resta inacessível. É em especial a psicanálise do pós-guerra que se ocupou de enfatizar a importância da qualidade das relações primordiais para o desenvolvimento do infante. Entre os anglo-saxões, Spitz (1980) discorre sobre o abandono afetivo e a necessidade de intimidade e estimulação; Bowlby (1984), sobre o apego e a importância do vínculo amoroso; Winnicott (2000), sobre o momento fusional entre a mãe e o bebê e o conceito de preocupação materna primária. Na França, na vertente aberta por Lacan, Françoise Dolto (1992) ressalta a capacidade a mais precoce do bebê de escuta da palavra do adulto e comunicação com o mundo através de seu corpo, enquanto Maud Mannoni (1980) destaca o efeito, sobre a criança, dos sintomas de seus pais. Não nos ocuparemos aqui do debate travado entre as diferentes escolas psicanalíticas: na perspectiva genealógica de Foucault - que não distingue a psicanálise das demais disciplinas $p s i$, identificadas no exercício da função de manutenção do regime disciplinar -, tanto uma psicanálise calcada na referência à soberania do pai quanto $\mathrm{a}$ que investe de poder a figura da mãe preservam a marca familiarista que reenvia à disciplina, reforçando o jogo estabelecido entre soberania familiar e funcionamento disciplinar. Aos pais, em especial à mãe, é reservado o papel de agentes da norma social vigente.

Contudo, se a interpretação psicanalítica tradicional tende a reconduzir toda a subjetividade ao pai e à mãe, uma leitura renovada da psicanálise, escapando 
aos limites da representação, coloca pai e mãe como meios, entre outros, de experimentação do mundo pela criança, e não como matriz única e inelutável dos afetos. Tournier (1973) diz que uma literatura infantil ou um livro para crianças - é aquela que provoca uma incitação ao criar, estimula a inventividade, está cheia de entrelinhas por onde embarcar, oferta linhas para o processo de criação (um devir-escritor). Esse mesmo sentido nos aponta Chaim Katz (1996) ao dizer de uma psicanálise da crianceria, esta abordagem afirmaria insistentemente o desejo como imanente (que não se deixa capturar), permanência aberta dos processos de subjetivação (um devir-criança).

\section{Devir-criança}

Vimos, acima, que a criança moderna torna-se imagem da esperança, de um vir-a-ser futuro. Porém, se, em vez de localizarmos a criança como vir-a-ser, reconhecermos, através dela, o devir, podemos admitir que o seu desenvolvimento não remete às exigências do futuro, mas às experimentações em que pode exercer as suas potências, compondo-se com os diferentes meios com os quais convive, incluindo as pessoas, entre elas, principalmente, os pais e irmãos. O desenvolvimento do bebê se faz por sintonias afetivas e por acoplamento cognitivo com os adultos (processo de subjetivação no dizer de Daniel Stern, 1989), servindo estes como meio à exploração do mundo, e não como matriz dos significados que vão povoar para sempre o inconsciente. $\mathrm{O}$ inconsciente é aberto, conectando-se com as forças que compõem encontros e acasos; mais do que reservatório traumático das representações, ele é a criança pulsante no adulto. A criança é um conjunto de potências devindo. A marca da criança é sua expressão por intensidades, sua aprendizagem pela experimentação e pelo jogo. A criança realiza o encontro real-imaginário. O imaginário infantil conta com um corpo com órgãos (seu corpo físico) e com um corpo acessório (sem órgãos) com o qual ela se compõe o tempo todo; por isso pode entrar em diferentes sintonias, realizar diferentes acoplamentos com o que vive . $^{3}$.

Os adultos e suas grandes teorias tendem a eliminar essa potencialidade da criança, fazendo dela um pré-adulto, devolvendo-a sistematicamente às compreensões únicas e verdadeiras, interpretando suas atitudes e condutas segundo as grandes referências (como se fossem únicas e verdadeiras). A criança não existe só pela faixa etária, ser criança é aceitar a aventura de se compor com as aprendizagens, deixar seu corpo descobrir experiências, explorar ambientes, percursos e emoções. Ser criança é aceitar a ousadia das viagens nômades, a coragem de se transportar para diferentes universos incessantemente, ao sabor de suas experiên- cias cognitivas e afetivas, para extrair conhecimentos e vivências intensivas, reencontrando real e imaginário.

Não se pode classificar a criança como fora da realidade ou alienada; ela realiza experiências de pensamento com o corpo todo e não busca estados de equilíbrio solidamente estáveis. Ela não para; embarca em paixões, em novidades, em aventuras, em excursões, em programas da televisão, nas conversas dos adultos, nas cores que se estampam em roupas e cadernos, nas luzes que passam pelas frestas e compõem personagens nas paredes... A criança é o que se liga nas chances de trajeto e traça cartografias de expedição. Inventa línguas para o que vê, sente e faz. Não se compõe com "permanências", arrasta sua expedição para outras terras. O que diferencia a criança do adulto é que este prefere mapas que indicam os percursos a seguir, localiza onde está, decide aonde quer chegar, compra o mapa com roteiros já delimitados e migra de um lugar para o outro. A criança cartografa em viagem, prefere a viagem. Os lugares, ela os localiza na sua carta, assinalando seus conhecimentos e movendo-se pelo produto de encontros e acasos, afetos-criança. Produz a si mesma.

A criança cronológica torna-se adulta, aceita os agenciamentos de subjetividade que a sociedade faz, que as instituições impõem, que os pais acham belos, bons, honrados; mas um devir-criança é a resistência a esses agenciamentos, e a criança sobrevem no adulto, sobressai-se em seus acessos de alegria, em sua curiosidade risonha, no bom-humor ou quando detecta uma nova suavidade nos encontros. Para um devir-criança, não existe o "homem", a forma-homem, o que há é um movimento de dissolução das formas criadas (Deleuze $\&$ Guattari, 1997, p. 19). O universo é para ser experimentado e vivido. Crescer não é em uma direção e sentido; é invenção de direções e sentidos. Desenvolver-se não é amadurecer e ficar adulto; é detectar potências de vida e dar-lhes existência. A criança sabe que a vida não é somente biológica e que a comunicação não é só pela palavra. A vida envolve múltiplos circuitos de conexão e múltiplas semióticas. Um bebê conecta-se com o móbile sobre o berço, com o próprio berço, com o paninho com que ronca e fuça; ela murmura com o nariz e com a baba, ela murmura com a teta e com a água do banho, sintonizada com a fluidez da matéria com a qual entre em contato direto (Kastrup, 2000, p. 379).

Um devir-criança é uma atividade cartográfica, produto das potências de afetar e ser afetado, mesclar "real" e "imaginário" como realidade atual. Guattari (1987) fala em devir-criança para afirmar que uma revolução, em qualquer domínio que seja, passa pela libertação prévia de uma energia de desejo e pelo fim de todas as relações de alienação que pesam sobre as mulheres, as crianças, as minorias sexuais, as sensibilidades atípicas, sobre o amor aos sons, às cores, às ideias... 


\section{A vertigem das crianças}

A mágica das crianças no brinquedo é que elas não só imitam; elas se tornam aquilo com que jogam, entram em zonas de vizinhança entre o que são e o que simulam nas brincadeiras. Esse estado é o mesmo que leva o artista à produção de arte, fazendo-o entrar em zonas de indiscernibilidade entre o racional e o sensível. $\mathrm{O}$ artista só pode tornar visíveis as sensações que ele mesmo experienciou. A experiência da sensação é a experiência do devir-artista; ela é equivalente às simulações da criança, é a experiência da conexão por afetos e da escuta áptica (escuta que capta o universo de fragmentos e os encaixa em uma dimensão cognitiva não racional).

$\mathrm{O}$ devir-criança e o devir-artista comungam a constituição de complexos de subjetivação e cognição que agenciam possibilidades individuais e coletivas e criam modalidades inéditas de aprender e conviver. A simulação da criança é o aprendizado que os artistas entendem e os adultos deveriam se permitir. A simulação infantil nos serviria para forjar figuras reterritorializadoras, sem recorrermos aos modelos identitários ou de verdade, mas às figuras finitas que dilatam as probabilidades da realidade e introduzem novas marcações de temporalidade. A diferença de um devir-artista ou de um devir-criança-em-nós está no fato de que com a primeira composição produzimos obras de arte e com a segunda composição produzimos a própria vida: a vida como obra de arte, na bela imagem que Nietzsche lança em $O$ Nascimento da Tragédia (Nietzsche, 1871/1992, p. 31), Foucault a recupera e Deleuze a retoma. É da criança produzir a vida. Seu desígnio é crescer, desenvolverse, inventar figuras para ser, abandonar essas figuras, inventar novas, experimentar personagens com os quais aprenda sobre si, seus afetos e seu poder de vida, experimentar amigos imaginários como desafio à lógica racional e aos valores morais e explorar o mundo com expedições cartográficas. As brincadeiras de faz-de-conta e o jogo com diversos papéis sociais desnaturalizam a vida cotidiana e modificam a estrutura perceptiva. No brinquedo, a criança pode imaginar comportamentos, atuar experiências vividas e investir competências mais avançadas do que as que consegue agir na realidade. Efeitos de subjetivação emergem dessas atividades. É da arte atingir esse estado infantil que não se esgota pela forma homem, colocando em existência visível o movimento de desmanchamento e engendramento das figuras da realidade, o surgimento de singularidades, a invenção de percursos e inscrição aos processos de vivência. Deleuze (1997, p. 78) coloca que "à sua maneira, a arte diz o que dizem as crianças".

O mundo da forma homem, o mundo onde impera o adulto, está na história da cultura ocidental moderna: uma civilização da consciência (da intelectualidade racionalista), superando a civilização trágica (da sabedoria) e dicotomizando instinto e razão, estética e conhecimento, arte e ciência. Aprender com a criança... É observá-la? É inverter a relação adulto-criança pela redução/eliminação da autoridade do adulto? É valorizar todas as atitudes da criança como puras, belas e boas, porque são crianças? É mais simples e mais complicado do que isso... Trata-se de acolher um devir-criançaem-nós sem deixarmos de ser os adultos cronológicos que somos. Nossa responsabilidade com as crianças é de adultos. É também a de educadores, puericultores, pediatras, pedagogos, psicólogos, psicanalistas, enfermeiros, recreacionistas, assistentes sociais, sociólogos, advogados e artistas.

A arte contemporânea traz esta figura de criança aos nossos olhos e ouvidos. Em 1998, o filme Central do Brasil (melhor filme no Festival de Berlim, 1998) produziu o encontro do adulto (uma mulher fria, racional, lógica, de olhar duro e reto) com a criança (um menino disposto a descobrir os afetos que podem mudar sua vida) e mostra-lhes a estrada, o percurso. Tudo acontece no percurso, nada está ou esteve nas paradas: vertigem. Essa vertigem é a do contato com o fora (a rua, a estrada) e a do lançar-se à aventura (Palombini, 1999). Walter Salles, o autor e diretor, em entrevista a Jurandir Freire Costa, diz: "é um filme de estrada, que é matéria viva, pronta a renovar-se e a remodelar-se, em função das surpresas que encontramos e da inventividade de todos os que colaboraram em sua realização" (Freire Costa \& Salles, 1998, pp. 7-8). De sua fala, destacamos: matéria viva / pronta a renovar-se / pronta a remodelar-se / em função das surpresas / em função da inventividade... O adulto do filme vai-se ressensibilizando, descobrindo a alteridade e presentificando uma mudança afetiva que o atravessa em todos os sentidos. A figura da criança é, ali, a da iniciativa de ação, coragem exploratória, desejo de expedição. A viagem do menino inverte o eixo norte-sul das migrações de população no Brasil e permite que ele redefina a sua própria história. Uma viagem profundamente emotiva ao coração de cada um dos personagens, define o diretor. A mulher passa a olhar para o outro, confrontada com o desconhecido, chance que a libertará de sua existência mesquinha. Tomada a iniciativa, empreendida a expedição, começa a liberdade. Liberdade não é a propriedade, não é a pureza de alma, não é a obediência e o temor a Deus ou ao poder. Liberdade é poder pegar a estrada, empreender a vida: viagem das crianças, vertigem.

\section{Os desafios para uma educação do cuidado}

Aprende-se a cuidar? Ensina-se a cuidar? Para cuidar, será preciso derrubar todos os movimentos de exclusão da alteridade que mapeamos no início 
do texto. Será necessária a abertura aos encontros de afecção, será necessário encontrar-se com o outro. A exclusão da alteridade é a exclusão do cuidado. Não é possível cuidar sem expor-se ao outro: uma educação do cuidado é uma educação da alteridade. Para corporizar a alteridade, há necessidade de um compromisso com o outro. Roubando as palavras de Deleuze (1985, p. 60), perguntamos: essa necessidade, trata-se de uma espécie de simpatia? De empatia? De identificação? É certamente mais complicado, diz Deleuze. É, antes, a necessidade de uma relação que não é nem legal, nem contratual, nem institucional. Uma relação, portanto, que escapa aos códigos da consciência, operando uma passagem entre a consciência e o inconsciente (entre a representação e a sensação). O único equivalente possível, nas palavras de Deleuze, seria, talvez, estar no mesmo barco e remar juntos:

o barco é uma espécie de jangada de Medusa, há bombas que caem à volta, a jangada deriva em direção a riachos subterrâneos gelados, ou então em direção a rios tórridos, o Orinoco, o Amazonas, pessoas remam juntas, que não supõem que se amam, que se batem, que se comem. (Deleuze, 1985, p. 60)

E Deleuze, então, explica: "remar juntos é partilhar, partilhar alguma coisa, fora de qualquer lei, de qualquer contrato, de qualquer instituição". Finalmente, a alteridade em prática: há um momento em que se faz necessário partilhar, em que é preciso colocar-se em sintonia com o outro, é preciso ir até ele, partilhar seu estado, há uma comunhão e o universo inteiro se abre a um devir-outro. Os processos de subjetivação entram em contato com a perda de sentido da forma-homem; impõe-se a invenção incessante de novas formas. Os modos de ver, dizer e julgar que aprendemos como verdadeiros ganham novas composições, novas perspectivas, conforme favoreçam a vida e afirmem sua potência criadora.

A criança, em sua condição de vulnerabilidade e sensibilidade, deixa-se afetar pelo outro. Um devircriança em nós assegura-nos essa escuta ética do e pelo outro nas situações que envolvem cuidado e educação em ato. Novamente um filme de Walter Salles e seus personagens criança e devir-criança vêm-nos à mente: Abril Despedaçado, prêmio do público jovem (Leoncino d'Oro) no Festival de Veneza de 2001. O território é o da supressão da alteridade: aqui não há a Roda dos Enjeitados, mas uma Roda de Bois que mostra um destino onde a diferença não pode entrar, a alteridade é enjeitada. A mãe, nesse filme, diz: "os mortos controlam os vivos". É que por gerações a morte do membro de uma família obriga a morte de um membro da outra, assim que a mancha vermelha do sangue derramado, exposta no varal, tenha-se tornado amarela. Outra Roda (ou a mesma): assassinato-varal-assassinato. Os mortos controlam os vivos: a regra, a moral, a identidade fixada, o assujeitamento, a morte, não o contato com a diferença, o contato com a alteridade, a vida. É um menino que, na história, rompe esse círculo, por seu desejo incontido de restaurar o direito à vida. Seu sonho é que a guerra sem sentido entre as famílias (a morte sem sentido) tenha fim. Também quer afirmar o amor ao outro, revelado no amor de criança pelo irmão amoroso e cuidador e o amor ao destino (amor fati). Não se trata de mudar de destino, mudar de vida, mas amar a vida, afirmar intensamente a vida, libertar-se do fatalismo, não da afirmação da liberdade. Vivendo sob o sol do sertão, sonha mergulhar em águas claras e ser cuidado por sereias. Um irmão mais velho morrera assassinado quando o levava às costas brincando de cavalinho. $\mathrm{O}$ irmão com quem estava acoplado afetivamente, em devir-irmão, devir-fraterno, devir do cuidado (um cuidado recíproco entre dois irmãos, cada um vivendo parte de si no outro: cuidado do e pelo outro, em ato) morreria da mesma forma brutal (destino fatalista das mortes desprovidas do contato com a autonomia, determinadas desde fora dos sonhos, desejos e apostas, posto que ausentes).

O menino afirma profunda e profusamente o cuidado com a vida. Sua exposição à alteridade é total, seu amor pela afirmação da vida é implacável. Qual o destino da criança: libertar o devir, lugar para o novo, criação. Um devir-criança afirma-se na criança do filme quando se depara com o circo, com a mulher que tem um livro de histórias cheio de figuras e lhe dá de presente, despertando novidades do cuidado. $\mathrm{O}$ cuidado dela é multivariado, convida a viver, a brincar, ao colo, ao corpo, à transgressão da Roda. O livro da criança é território de sonhos e imaginação. O território da criança é sonho e imaginação (imagem cristal). O menino vai ao encontro de seu destino abrindo um paradoxo: a vida se impôs à morte. Ele morre em lugar do irmão, mas trata-se de escolha sua, não de assassinato como na Roda assassinato-varal-assassinato. O menino libertou o irmão, exerceu e afirmou a escolha pelo viver: os mortos não controlam os vivos! [E se os boi decidisse parar de rodar?] É a mãe quem diz novamente ao pai atônito (seu mundo caiu, não havia inscrição para este ato de cuidar, não havia o cuidar, não havia tempo para o si mesmo): acabou! É a mãe que enuncia a secção da linha de tempo, a abertura de uma deriva (o curso de tempo foi fraturado, não poderá seguir mais a mesma linha), mas o cuidado, este não está na parentalidade (também ela não zela pelos vivos, sofre com os vivos, mas zela pelos mortos), está na colateralidade (está entre irmãos, não entre mãe/pais e filhos), no dizer-se respeito um ao outro ou um pelo outro, não na ascendência, um sobre o outro ou para com o outro, está na amizade.

Um devir-criança é máquina de vida. A educação do cuidado começa no contato com o devir-criança da 
alteridade. Sem o poder da sensibilidade e o deixar-se afetar pelo outro não é possível o cuidado. A vida é o que excede no vivo; não é a sobrevida, é o que no vivo se dá como abertura temporal à criação. A vida é autopoiese. Deixa para trás territórios do sempre o mesmo, de reposição reiterativa do mesmo, tendo à frente existências virtuais, contato com a diferença, não a reiteração do ser, mas o amor ao tornar-se, amor fati, singularização, amor à infância. Walter Salles (2007b) refere-se a esse seu filme contando que optou por um narrador que, "no meio do caos, ainda tinha conseguido preservar alguma lucidez e inocência" (o menino) e que se interessou em "investigar a relação entre os irmãos" (pessoas que se dizem respeito profundamente).

Educação do cuidado com a imagem da criança: sonho e imaginação de um cuidado de afirmação da vida. Educação do cuidado: rejeitar as Rodas de enjeitar alteridade e reivindicar as Rodas de criatividade; rejeitar as rodas desprovidas de autonomia e reivindicar as rodas de alegria. A Educação como rejeição dos círculos viciosos e afirmação dos círculos criativos, na tão bela imagem de Varela (1994) sobre a experiência da autonomia como um paradoxo e não uma verdade na invenção da existência. O Cuidado em ato como paradoxo do atual: entrecruzamento do real (o instituído; as vigências) com o virtual (o instituinte; as potências); como paradoxo da "resistência e criação" (Ceccim \& Capozzolo, 2004): resistência à sujeição (assujeitamento) e às determinações / condicionamentos (heteronomia); criação de potência de vida, produção de si e do mundo. Viagem das crianças: sonho e imaginação.

\section{Notas}

1 Darnton (1986) conta que aquilo que torna comoventes os contos populares não é seu final feliz como lhes acontece depois do século XVIII (principalmente quando se tornam contos infantis). Não eram dirigidos às crianças e sugeriam cautela, e não bom comportamento. Apontavam que nenhuma moral governa o mundo em geral e que o bom comportamento não determina o sucesso. Desastres não podem ser prevenidos, nem explicados, devem ser simplesmente suportados.

2 A pediatria mesma, como especialidade de conhecimento médico, só vai surgir no século XX.

3 Deleuze e Guattari (1996) retomaram do ator e teatrólogo Antonin Artaud a expressão Corpo sem Órgãos para destacar a necessidade de aprendermos a coragem para experimentar a vida.

\section{Referências bibliográficas}

Ariès, P. (1979). História social da criança e da família. Rio de Janeiro: Zahar.

Badinter, E. (1985). O amor conquistado: o mito do amor materno. Rio de Janeiro: Nova Fronteira.
Bowlby, J. (1984). Apego e perda: apego (Vol. 1). São Paulo: Martins Fontes.

Ceccim, R. B. \& Capozzolo, Â. A. (2004). Educação dos profissionais de saúde: a prática clínica como resistência e criação. In J. J. N. Marins, S. Rego, J. B. Lampert, \& J. G. C. Araújo (Orgs.), Educação médica em transformação: instrumentos para a construção de novas realidades (pp. 346-390). São Paulo: Hucitec.

Darnton, R. (1986). Histórias que os camponeses contam: o significado de mamãe ganso. In O grande massacre de gatos e outros episódios da história cultural francesa (pp. 21-101). Rio de Janeiro: Graal.

Deleuze, G. (1985). Pensamento nômade. In S. Marton (Org.), Nietzsche hoje? Colóquio de Cerisy (pp. 56-76). São Paulo: Brasiliense.

Deleuze, G. (1992). Dúvidas sobre o imaginário. In Conversações: 1972 - 1990 (pp. 87-89). Rio de Janeiro: Editora 34.

Deleuze, G.. (1995). Foucault. São Paulo: Brasiliense.

Deleuze, G. (1997). O que as crianças dizem. In Crítica e clínica (pp. 73-79) São Paulo: Editora 34.

Deleuze, G. \& Guattari, F. (1996). Como criar para si um Corpo sem Órgãos. In Mil platôs: capitalismo e esquizofrenia (Vol. 3, pp. 9-29). Rio de Janeiro: Editora 34.

Deleuze, G. \& Guattari, F. (1997). Devir intenso, devir animal, devir imperceptível. In Mil platôs: capitalismo e esquizofrenia (Vol. 4, pp. 11-113). Rio de Janeiro: Editora 34.

Dolto, F. (1992). A imagem inconsciente do corpo. São Paulo: Perspectiva.

Foucault, M. (1992). O nascimento da medicina social. In Microfisica do poder (10 ed., pp. 79-98). Rio de Janeiro: Graal.

Foucault, M. (2006). O poder psiquiátrico. São Paulo: Martins Fontes.

Freire Costa, J. (1989). Ordem médica e norma familiar ( $3^{\mathrm{a}}$ ed.). Rio de Janeiro: Graal.

Freire Costa, J. \& Salles, W. (1998, 29 de março). Um filme contra o Brasil indiferente: o psicanalista Jurandir Freire Costa entrevista Walter Salles, diretor do filme Central do Brasil, premiado com o Urso de Ouro do Festival de Berlim. Folha de São Paulo, Caderno Mais!, pp. 7-8.

Freud, S. (1972). A interpretação dos sonhos (Parte I). In Edição standard brasileira das obras psicológicas completas (Vol. 4). Rio de Janeiro: Imago. (Originalmente publicado em 1900)

Freud, S. (1972). Três ensaios sobre a teoria da sexualidade. In Edição standard brasileira das obras psicológicas completas (Vol. 7, pp. 123-252). Rio de Janeiro: Imago. (Originalmente publicado em 1905)

Freud, S. (1974). Análise de uma fobia em um menino de cinco anos. In Edição standard brasileira das obras psicológicas completas (Vol. 10, pp. 13-154). Rio de Janeiro: Imago. (Originalmente publicado em 1909)

Freud, S. (1974). Sobre o narcisismo: uma introdução. In Edição standard brasileira das obras psicológicas completas (Vol. 14, pp. 85-119). Rio de Janeiro: Imago. (Originalmente publicado em 1914)

Guattari, F. (1987). Devir criança, malandro, bicha. Revolução molecular: pulsações políticas do desejo ( $3^{\mathrm{a}}$ ed., pp. 64-69). São Paulo: Brasiliense.

Kastrup, V. (2000). O devir-criança e a cognição contemporânea. Psicologia: reflexão e crítica, 13(3), 373-382.

Katz, C. S. (1996). Crianceria: o que é a criança. Cadernos de Subjetividade, 4 (n. spe.), 90-96.

Luzán, J. (1998, 20 de junho). Paul Klee: mostra reúne na Espanha a obra do artista suíço que misturou pintura e música. Zero Hora, Segundo Caderno/Cultura, p. 12. 
Mannoni, M. (1980). A criança, sua doença e os outros (3 ${ }^{\mathrm{a}}$ ed.). Rio de Janeiro: Zahar.

Nietzsche, F. (1986). Ecce homo: como alguém se torna o que é (P. C. Souza, Trad., $2^{\mathrm{a}}$ ed.). São Paulo: Max Limonad. (Original publicado em 1888)

Nietzsche, F. (1992). O nascimento da tragédia ou Helenismo e pessimismo (J. Guinsburg, Trad.). São Paulo: Companhia das Letras. (Original publicado em 1871)

Oliveira, H. (1993). A enfermidade sob o olhar da criança hospitalizada. Cadernos de saúde pública, 9(3), 326-332.

Palombini, A. de L. (1999). O louco e a rua: a clínica em movimento mais além das fronteiras institucionais. Educação, subjetividade e poder, 6, 25-31.

Salles, W. (Diretor). (1998). Central do Brasil [DVD]. Barueri, SP: Europa Filmes.

Salles, W. (Diretor). (2001). Abril despedaçado [DVD]. Barueri, SP: Imagem Filmes.

Salles, W. (2007a). A imagem e o som: alguns conceitos do filme. Central do Brasil. Acesso em 18 de janeiro, 2008, em http:// www.centraldobrasil.com.br/fr_sin_p.htm

Salles, W. (2007b). Notas do diretor: o processo de adaptação. Abril despedaçado. Acesso em 18 de janeiro, 2008, em http:// www.abrildespedacado.com.br/pt/entrada pt.htm

Severo, A. M. D. (1996). Roda dos expostos II. Porto \& Virgula, 4(29), 36-39.

Stern, D. N. (1989). O mundo interpessoal do bebê: uma visão a partir da psicanálise e da psicologia do desenvolvimento. Porto Alegre: Artes Médicas.

Spitz, R. A. (1980). O primeiro ano de vida. São Paulo: Martins Fontes.

Tournier, M. (1973). Existe uma literatura infantil? O correio da Unesco, 1(1), 33-34.

Varela, F. (1994). O círculo criativo: esboço histórico-natural da reflexividade. In P. Watzlawick (Org.), A realidade inventada - como sabemos o que cremos saber? (pp. 302-316). Campinas: Workshopsy.
Winnicott, D. (2000). Da pediatria à psicanálise: obras escolhidas. Rio de Janeiro: Imago.

Zavaroni, D. de M. L., Viana, T. de C., \& Celes, L. A. M. (2007). A constituição do infantil na obra de Freud. Estudos de psicologia, 12(1), 65-70.

Ricardo Burg Ceccim é sanitarista, mestre em Educação e doutor em Psicologia Clínica, professor da Faculdade de Educação, da Universidade Federal do Rio Grande do Sul e coordenador do EducaSaúde - Núcleo de Educação, Avaliação e Produção Pedagógica em Saúde. Endereço para correspondência: Av. Paulo Gama, 110, Prédio 12.201, Sala 409, Bairro Farroupilha, Porto Alegre/RS. CEP 90.046-900

Email: burg.ceccim@ufrgs.br

Analice de Lima Palombini é psicanalista, mestre em Filosofia e doutora em Saúde Coletiva, Professora do Instituto de Psicologia, da Universidade Federal do Rio Grande do Sul e pesquisadora do EducaSaúde - Núcleo de Educação Avaliação e Produção Pedagógica em Saúde. Endereço para correspondência: Av. Paulo Gama, 110, Prédio 12.201, Sala 409, Bairro Farroupilha, Porto Alegre/RS. CEP 90.046-900

Email: analicepalombini@uol.com.br

\section{Imagens da infância, devir-criança e uma formulação à educação do cuidado}

Ricardo Burg Ceccim e Analice de Lima Palombini

Recebido em: 26/02/2008

Revisão em: 28/3/2009

Aceite final em: 16/04/2009 